\title{
THE CHARACTER OF CIRCE IN THE ODYSSEY
}

\author{
J D McClymont (University of Zimbabwe)
}

\begin{abstract}
The article describes the character of Circe in the Odyssey, emphasizing that she has not only an evil but a positive side to her character. The implications of her being a witch, swearing an oath to Odysseus and being a god are explored. She is also briefly compared with other characters in the Odyssey.
\end{abstract}

One of the most noteworthy incidents in the Odyssey is the visit of Odysseus to Aeaea, where the enchantress Circe turns his crewmen to animals. Circe is the most well-known witch-figure in Greek mythology, and indicates an early presence of belief in magic in classical literature. As an enchantress, however, she is not merely a special effect in a heroic story. There is more to her than meets the eye. There is an overly simple image of Circe as a typical example of witchcraft, which we can trace in Perkins' Discourse on the Damned Art of Witchcraft. For this seventeenth century author, Circe is viewed as a historical example of the sort of black witch in which he believed (Anglo 1977:10), and this "evil-witch" idea certainly has precedent in classical literature, if we consider the story of Meroe in Apuleius as a malevolent figure, who turns Aristomenes into an animal (Frangoulidis 1999:381). There is a certain sexual overtone to Apuleius' story - Aristomenes watches or looks on the woman and becomes an animal; and we may expect Circe's transformation of men into animals to have a similar significance. Yet in ancient literature Circe can be portrayed in a more positive light: for example as the "golden" Circe who is the daughter of the sun god (Weber 1999:326).

\section{Circe as witch or magician}

In exploring the question, "Who is Circe?" we may start by asking: "What is a witch or a wizard anyway?" Definitional debates about magic versus religion yield a possible answer, that whereas religion relies on divine intervention, with magic there is more emphasis on personal control by the magician (Hutton 1991:289-90). Though magic does not exclude divine influence (Od. $10.277 \mathrm{ff}, 289-292)$, this influence is not a miraculous or supernatural interference with the course of nature but is a part of nature, which the magician employs for his/her own purposes.

An apparent consequence of this in Homer, important for the Odyssey, is that the magician is assimilated to any divine influence that he / she comes into contact with. The power of the gods accessed in magic is natural, and so is the activity of the magician. The powers of a magician and of a god are both natural, and thus similar. Hence Circe is already reckoned a goddess (10.571-574) and similarly the shapechanger Proteus is counted among the gods $(4.384-386,397)$. Nor, similarly, is it surprising that Aeolus, whom we meet in the Odyssey $(10.2,19-22)$ as possessor of a magic wallet controlling the winds, is in later literature viewed as a god in his own right. In Aeneid 1.76-80 Aeolus is permitted to feast with the gods and is given the godlike office of power over the winds generally, not merely isolated winds controlled by witchcraft (Aeneid 1.81-86) and is thus presumably a god in his own 
right. Moreover, in the Metamorphoses (11.561-562) Aeolus is "invoked" by his daughter Ceyx and is thus in the position of a god. Ehwald (1966:269) identified Ceyx's father as Aeolus, while Otis $(1966: 233$, 244) identified Aeolus and Lucifer as gods, and saw a theological significance, in terms of the indifference of the gods, in the apparent lack of interest they showed in Ceyx's death. Thus the Homeric magician Aeolus was later divinised; while the magicians Circe and Proteus were divine already. In the Homeric worldview a magician or witch is not an enemy of the divine, ranged against it as darkness against light. It is more correct to say that the Homeric magician or witch by his / her art becomes a divinised or god-like human.

If divine influence is a part of that nature which magic users try to make use of, then any magic user is dabbling with the sphere where the gods are at work and to that extent is playing the god. Yet not all who play the god, so to speak, with magical assistance become gods in the proper sense. Odysseus, though he uses magical medicine to defend himself against Circe (Od. 10.292), and although he has the heroic title of "god-like" (7.133), is never styled a god in the same way as Circe is styled a goddess. The magic user is assimilated to the gods, but this assimilation can be incomplete or more complete. There are magical experts and non-experts, and Odysseus is one of the non-experts. He is inferior to the divine, while Circe is a magical expert who is divine.

Care should be taken not to read into Homer a modernistic contrast between the rational versus the magical. In ancient times the magical and the rational were not invariably distinct: in fact even Plotinus' philosophical mysticism is linked with magical thought by Mazur (2003:49). Thus the interpretation of witches in literature as projections of the irrational on to woman (Lambert 1998:140) does not appear to apply to the case of Circe in Homer. As an expert in her art Circe is intelligent rather than irrational. Nevertheless Circe and her witchcraft and femininity may be fairly understood as being, for Homer, something difficult to understand, and therefore dangerous.

The Homeric idea of divinity does not rule out characteristics like vulnerability or evil. In the Odyssey 4.397 we are told that for a mortal to tame a god is difficult (not impossible) and it is also obvious that Circe in the Odysseus myth has the character of a foe to begin with. Yet it would be a distortion to stereotype Circe as initially a monolithic "black witch". The interpretation that has Circe starting off as an evil witch and turning into a gentle sympathetic personality after meeting Odysseus (Whitman 1958:300) corresponds to a real moral transformation in Homer's narrative but should not blind us to a positive side possessed by Circe from the beginning.

The positive side is seen when Circe is ascribed excellence in the performance of woman's proper work; her weaving is divine (Od. 10.222-223). This is in contrast to what Odysseus fears from Circe's enchantments, to be unmanned while naked (10.341). Circe's invitation to bed is dangerous (296-301) which means that Homer represents her as sexually threatening, and to that extent violating the traditional role of woman. Yet in her weaving Circe fulfils that role to perfection. There are two sides to Circe's character, that of sexual temptress or evil witch and that of one who knows a woman's proper tasks and can excel in them. She has a good and evil side to her 
from the beginning; it is not a simple case of transformation from evil witch to good person.

The positive side to Circe is also seen in the nature of her divinity; technically Circe, as daughter of Helios, is actually a nymph, which makes her a sort of benign power associated with nature (Seymour 1963:444).

\section{The oath of Circe}

Circe gains power over those she transforms into animals by deceit, or drugging the food (Od. 10.290); Stanford (1959:372, 374) argued that Circe's wand is not necessarily magic but is more like a rod for controlling animals. It would therefore stand not so much for magical power as for dominance obtained over the male sex. Odysseus faces not only enchantment but subjugation to woman; thus the oath Circe is made to swear, though it may seem redundant in view of Odysseus' herbal protection (Page 1973:57), is a safeguard against unmanning or subjugation over and above the danger of enchantment. Even without magical drugs, a beautiful woman with an enchanting voice (Od. 10.220-221) is still dangerous - remember the Sirens? - and thus Odysseus' oath is maybe not as redundant as it seems.

A further dimension we may discern in the oath is that it appeals to Circe's piety and better nature. It is not the same as a promise made in a secularist society; for Homeric society an oath counts for far more and is underpinned by a religious worldview. The swearing of the oath brings out a side of Circe that is in contrast to the dominating aspect of her personality; it leads her to obey a social compact, honour the gods and interact with other humans as equals rather than objects of domination. It is almost redemptive.

That is why Odysseus preserves himself with the oath as well as the moly. The moly remedy is a stratagem of blind nature against blind nature, potion against potion, force against force. It is aimed at an impersonal threat. But Circe is not impersonal and her character has many levels. Odysseus seems to confront her at three levels. There is an evil level where her medicine is matched with his. Circe's medicines are baneful medicines, pharmaka lugra (236), in contrast to Odysseus' pharmakon esthlon (292) or good medicine. There seems to be a neutral level where Circe's rod meets Odysseus' sword (293-294); the rod and sword in Book 10 are described more neutrally than the medicines, not explicitly contrasted as good and evil. Finally there is a good level where Odysseus and Circe agree on an oath to swear and thus are able to coexist honourably as persons. In the strict sense being a goddess, Circe is actually superior to Odysseus, but with the help of Hermes, Odysseus manages to eventually get the better of Circe's medicine and achieve a sort of equal interaction with her by virtue of the oath.

Given that there is a level where Circe appears to be beaten and another level where, via the oath, she seems to be Odysseus' social partner, can we say that Odysseus has won an unambiguous victory? Is Circe subjugated or is she Odysseus' equal? A surface reading may suggest that the oath is simply an instrument for subjugating or tricking Circe, but we cannot take this for granted once we realize that the oath is conceded by Circe from a position of honour. Odysseus uses the words, 
"Unless you deign, goddess" (343) and thus receives the oath from Circe as from a superior.

The oath is a precondition for Odysseus having sex with Circe (337-344). Since the purpose of this sex is to gain the release of Odysseus' companions (297298) we may in the interests of parsimony presume against any other motive for the sex. We have no reason to believe that Circe is being induced by sexual motives to give her oath, and we may take Odysseus' request for the oath at face value. Odysseus questions Circe's conduct rather than forbidding it, and requests the oath rather than demanding it - the verb keleuo (345) can be understood in the sense of urgently beseeching rather than ordering (Liddell \& Scott 371). This implies that he is not forcing her, that her response to him is willing. So in some respects, at least, Odysseus' hold over Circe is something freely conceded him.

\section{Circe's divinity}

The victory is also ambiguous once we realize that Circe remains technically superior to Odysseus as a god to a mortal. What shall we say of Odysseus' immunity to Circe's charms, and his securing the release of his men? It may be conceded that Odysseus' use of moly involves him in magic and assimilates him somewhat to Circe. But there is an important difference: Circe's magic is her area of expertise, and she is herself a goddess by Homeric standards. She does not require the aid of another god to do her magic. With Odysseus it is otherwise. He is a mortal and requires the aid of Hermes both in the obtainment of his medicine and the advice of how to proceed in order to secure Circe's goodwill (Od. $10.277 \mathrm{ff}, 292 \mathrm{ff}$ ). Hermes also prepares the ground in advance by warning Circe of the coming of the hero (330-331), possibly ensuring in advance that Odysseus will be attractive to her.

Circe, noting Odysseus' immunity to her potion, attributes it to his having a mind that cannot be enchanted (329). Yet Odysseus' apparently magic-proof mind is a deception since his immunity comes from a drug. Odysseus plays a trick on Circe even as she tricked his men. Shortly after observing Odysseus' immunity, Circe desires sex with him (333-335) which Odysseus will now use to induce Circe to release his men (297-298). Does it lessen Odysseus' victory that he does not really have the unenchantable mind Circe thinks he has? Perhaps not in the eyes of the original author, since a culture that values the cunning of Odysseus as polumechanos (456), or a person of many devices, might allow the successful faking of excellence to be a praiseworthy accomplishment of cunning, particularly if it wins the favours of a woman. We may think also of the fairy-tale "Doctor Know-It-All" where the character assumes the appearance of learning that he does not possess, yet is in no way lessened in the estimation of the reader (Sideman 1970:457-462).

Nevertheless the fact remains that Odysseus is not a god and he wins his victory not by an unenchantable mind, like a god, but by the aid of Hermes and his medicine. He requires Circe's consent to free his men, being unable to do it on his own (Od. $10.382 \mathrm{ff}$ ). And towards the end of Book 10 when he has Circe's goodwill his inferiority to the divine becomes manifest. When he has to leave, he needs Circe's direction as a precondition for arriving home; further, the knowledge of how to get 
home requires a magical ritual, and in this area he depends on Circe for instructions and know-how (483 ff, $488 \mathrm{ff}, 504-540$ ). The challenge of visiting the Underworld causes Odysseus some anxiety (496 ff) and Circe is placed in the position of consoler and even comforter of Odysseus. She gives him a favourable wind for his homeward journey (11.6-8).

Towards the end of the story, then, Circe is Odysseus' superior; she ends up as a goddess speaking with human voice (11.8). She started as a god, she ends up a god. If she was evil, it was as a god that she sinned; this is possible in Homeric theology. And if she has been redeemed in the Odyssey, it is as a god that she has been redeemed.

How could the mortal Odysseus morally redeem a goddess? Of himself he couldn't and he didn't. His victory over Circe and the oath whereby he brings out the goddess' better side all proceed in the final analysis from the wisdom and art of Hermes, who gives Odysseus the strategy, the medicine and the reputation which precedes him. Hermes is the true redeemer of Circe, and Odysseus acts throughout in dependence on Hermes' aid. He has been an instrument of the god. As soon as Hermes' power reaches its full intended effect, with the swearing of the oath and the deliverance of Odysseus' companions (10.297-301) - and note well that Hermes ascribes salvation to himself, not Odysseus (286) - from then on, Odysseus has no pre-eminence over Circe. When Circe makes the sacrifice to send Odysseus on his way, she acts without his say-so; while he and his crewmen are worried at their journey, Circe is unperturbed and acts efficiently as a witch and a goddess (570-575). She is clearly no longer evil and is Odysseus' superior.

It would be a mistake to think of Circe as being redeemed from a life of witchcraft. Her witchcraft is linked with her divinity, and we leave her in the Odyssey (11.6-8) practicing witchcraft in a benevolent manifestation, sending the hero home. She may have given up her evil ways but she has not lost her powers, and she is still described as a goddess (8). She has not had to give up her magic; rather, her powers have found a better expression. We may recall the effect of the change of Odysseus' friends back from beasts into humans, which is not so much a disenchantment as a benevolent re-enchantment, for she transforms them into younger and better persons (10.395-396). Even the original enchantment into beasts had a benevolent side, in as much as the beasts are traditionally held to have been not wild but tame: there is no instance in Homer of a beast enchanted by Circe behaving in a hostile fashion (Grant \& Hazel 1979:91).

Circe is called deine theos (11.8). The adjective deinos has many meanings (Liddell \& Scott 152-153). It may have the sense of "terrible" or "awful", the sense favoured in the translation of Butcher \& Lang (1883:172) who refer to Circe as a "dread goddess". Yet this translation may be incorrect. After Circe releases Odysseus' crew she does not behave in a fashion that really seems horrific or frightening. So perhaps another meaning of deinos applies in 11.8. Deinos has the possible meanings of "powerful for good or ill", of "wondrous", "clever" or "skilful". Circe's magical talent makes all of these other meanings applicable to her. So possibly 11.8 is representing Circe not as frightening but as an "awe-inspiring goddess". 
Moreover, the word audeessa ("speaking with a human voice") points to a humanlike and gentle side to Circe's character. If she is awe-inspiring as a goddess, she still is regarded as speaking with a human voice, which calls to mind her singing voice when we first met her (10.221). In her final appearance in the Odyssey Circe retains the excellence both of a goddess and of a woman, and the development of her character reaches perfection as we finally bid her farewell.

\section{Circe and other characters}

Circe is not the only female figure, or magician-figure, encountered in the Odyssey. Another major figure is Calypso, the nymph who keeps Odysseus captive in Ogygia (Od. 1.14). Like Circe, Calypso is a goddess, and like her she swears an oath not to harm Odysseus, being requested by a similar formula to that used with Circe (5.178179, 184-187). Calypso and Circe have contrasting characters, in that Circe appears less emotional. When Odysseus has to eventually leave her, she is sensible and practical about it, and does not, like Calypso, try to restrain him, or complain (Bradford 1963:118). Calypso on the other hand is clearly very much affected by Odysseus' having to go, and has some excuse for displeasure because Odysseus has been a rather ungallant and cold lover to her; in fact, Odysseus seems to have enjoyed himself more with Circe, for he has to be badgered by his men to leave her, whereas with Calypso he seems to spend his time in sadness (Bradford 1963:190,193). This is despite the fact, noted by Jones (1988:59), that Calypso has sufficient concern for Odysseus to feed and bathe and sleep with him personally - in contrast to Nausicaa, who is more distant and lets her slaves feed and bathe him.

Nevertheless Calypso is by no means a perfect character. She has sworn an oath at Odysseus' request because he distrusts her promise that she will simply let him go home, just like that (160-179), and his reference to the dangers of sea-going (174-176) may reflect a suspicion of the wind she is going to send him (167). Calypso, in contrast to Circe, appears as a trickster of Odysseus rather than one tricked by him. After swearing her oath, she then tries to hold him back from going by speaking of his evil fate (206 f), and the advantages of staying with her (208-210) and finally she appeals to her own sexual charms (211-213). Odysseus' distrust of her previous permission to let him go home seems not without reason, since she is trying to impede his journey back home. Her declaration that she would readily (prophrass (a) Liddell \& Scott 612) send him away (161) was a lie. By contrast Circe, when asked to send Odysseus and his friends back home, is willing to detain them in her house no longer, and Odysseus seems to trust that she will fulfill her promise (10.483-489).

Calypso seems thus less trustworthy than Circe - her very name derives from kalupto which means "I cover up". Jones (1988:91) concedes that in terms of magic power Circe is more of a threat to Odysseus, although noting that in the Odyssey Homer does appear to be de-stressing the magical element in favour of the social interaction between the characters. Yet Jones notes that in the end Circe is shown to have Odysseus' best interests at heart. Calypso's selfishness, on the other hand, "contrasts well with the value Penelope places on a long-term relationship valued by 
both partners" (Jones 1988:214). Odysseus is, to be sure, offered immortality by Calypso, which may appear at first sight to be an unselfish offer; but Buffiere (1956:371), while agreeing that immortality is not to be refused without serious reasons, points out that the offer must be serious in the first place. Given the deceit Calypso is resorting to in order to prevent Odysseus leaving, we may well have our doubts about her offer of immortality.

Another bad side to Calypso's character, and one which we don't see in Circe, is disrespect and resistance towards the gods. When asked by Hermes to let Odysseus go, she complains against divine interference in her fun $(5.118 \mathrm{f})$ and tells stories presenting the gods in a bad light (121 ff). She says in an impolite fashion that Odysseus may go (erreto) if Zeus commands (139) - the word can also mean "let him perish" (Liddell \& Scott 272) and although Calypso promises not to harm him (144) the double meaning contributes to the negative appearance of Calypso's character. Calypso's tone is one of resistance to the divine will, and Hermes enjoins her to show respect for Zeus' wrath (146 f). We may note that Hermes has to confront Calypso in a more direct fashion than Circe, perhaps an indication of Calypso's greater obstinacy in the face of the divine will.

Despite the affection felt by Calypso, and the genuineness of her suffering Virgil's Dido in the fourth book of the Aeneid is probably modeled on Calypso Circe appears, in the light of the foregoing observations, a better character than Calypso in certain respects. A modern reader might view Circe's lack of Calypso's emotional sensitivity as a negative feature. Yet in order to understand how Homer sees this, we should perhaps look on Circe's temperament not with the viewpoint of a modern, used to romanticizing tragic heroines, but with the viewpoint of an ancient, for whom female emotion was a sign of weakness. This viewpoint is exemplified by the portrait of Aphrodite as cowardly, and the contempt shown for her putative fears about war and her concern with the love of women, in the Iliad (5.330-331, 348-352). Note that the goddess is shown as suffering greatly, yet is described contemptuously as analkis. From the ancient point of view the emotional sensitivity of Calypso is perhaps more of a weakness than a strength, and Circe's lack of emotion at Odysseus' departure may be something that counts in her favour (Bradford 1963:118). The fact that Odysseus seems to like Circe's company, yet is unhappy in Calypso's (Bradford 1963:190) may be a clue to the preference of the author of the Odyssey.

Whitman (1958:298-300) nevertheless notes that in the course of the Odyssey Odysseus changes from a self-reliant hero to someone less self-assured; his encounter with the strange and mysterious, which increases as his adventures progress and is firmly under way when Circe sends him off to the land of the dead, leads ultimately to the "fading of an earlier and smaller self" (Whitman 1958:299). Whitman indicates that after the years with Calypso "all former disguises are stripped away." This seems to give a positive slant to Odysseus' sadness in Ogygia, and to indicate that the contrast between Odysseus' pleasure with Circe and his sadness with Calypso signifies a personal transformation rather than anything to do with the characters. Whitman (1958:299) indicates that the change lies more in Odysseus' journey to the dead than in the arts of Circe herself, and that if Odysseus' journey to the dead is the reason for his change of character, this at the same time minimizes the role of 
Calypso in his sadness. Nevertheless, can we say that Calypso's retention of Odysseus and her attempts to delay him are completely without effect on his sadness? That they don't hold him back from his homeward journey? If, as seems plausible, the author's sympathies are with Odysseus, and he and the reader are waiting for him to eventually reach home, then it seems Calypso at the end of the day is holding him back against his will, while Circe does not hold him back against his will but even helps him on his way.

It may be true as Whitman seems to be saying that both Calypso and Circe contribute to a maturing personal transformation of Odysseus' character through encounter with the strange and mysterious. Yet the fact that the reader is presumably meant to identify with the hero means that Odysseus' positive attitude to Circe's company and his negative attitude to Calypso's are judgements in which Homer expected his audience to share. Yes, Odysseus' stay in Aeaea and Ogygia helped mature him; but the stay in Aeaea was a happier one. He was refreshed and helped by Circe, whereas he endured Calypso. Even Whitman's approach to the character transformation of Odysseus does not rule out the theory already suggested, that Homer has a preference for Circe over Calypso indicated by the difference of the experiences Odysseus has with both.

In addition to comparing favourably with Calypso in the areas mentioned earlier, those of trustworthiness, unselfishness and piety, Circe also compares favourably with two other magic-users in the Odyssey: Aeolus and Proteus. Although Aeolus treats Odysseus hospitably at first $(10.14-16,19)$ and gives him the aid of the winds, nevertheless when Odysseus meets with misfortune through the premature opening of the bag (46 ff) and returns with an account of his plight (68-71) Aeolus dismisses him abruptly with the word $\operatorname{err}(e)$, repeated twice $(72,75)$ and calls him "most shameful of living beings", elenchiste zoonton, thereby almost denying him human status. Circe, although superior to Odysseus in status as a goddess, does not draw attention in a critical fashion to Odysseus' moral shortcomings, and Odysseus escapes the fate of "dehumanization" by Circe's power of transforming people into beasts. Ultimately Odysseus' men end up no longer being dehumanized but rehumanised (10.395-396). Circe may thus be positively contrasted with Aeolus, who ultimately dehumanizes Odysseus while Circe does not.

Proteus may be treated as a divinised magician, on account both of the reference to his olophoia or pernicious arts (4.410; Stanford 1967:213; Liddell \& Scott 485), and his Egyptian nationality (4.385) which makes him human in origin rather than a god from the beginning. According to Stanford (1967:279) Proteus was described by Herodotus as king of Memphis; moreover "Berard compares Prouiti, a title of the Pharaohs who ... were credited with magical powers." Proteus, in comparison with Aeolus and Circe, is a character most unwilling to help people or be approached; he transforms himself into a series of non-human and sometimes frightening shapes (455-458) before asking Menelaus what he wants, and even then indicating that he has been caught unwillingly (463). Proteus is thus presented in the Odyssey as one who is unwilling to help mankind; Aeolus, as one who is initially willing to help Odysseus, but eventually unhelpful; Circe, as one who is glad to assist Odysseus in the end. 


\section{Conclusion}

This article gathered evidence from the Odyssey to show that Circe possesses some good qualities and that her character displays various facets. She is not an unqualified villain, but compares favourably to the magicians Aeolus and Proteus. In certain respects she compares favourably even with the nymph Calypso, whom a modern reader of Homer may be inclined to deem more sympathetic on account of her suffering. Despite the danger implied in her magic, Circe does not conform to a stereotypical idea of the "wicked witch".

\section{BIBLIOGRAPHY}

Anglo, S (ed.) 1977. The Damned Art. London: Routledge \& Kegan Paul.

Bradford, E 1963. Ulysses Found. London: Hodder \& Stoughton.

Buffiere, F 1956. Les Mythes d'Homere et La Pensee Grecque. Paris: Societe D'Edition "Les Belles Lettres".

Butcher, S H \& Lang, A 1883. The Odyssey of Homer. London: Macmillan \& Co.

Ehwald, R 1966. P. Ovidius Naso: Metamorphosen (Zweiter Band). Zurich: Weidmann.

Frangoulidis, S A 1999. Cui videbor veri similia dicere proferens vera? Aristomenes and the witches in Apuleius' tale of Aristomenes. CJ 94(4):375-391.

Grant, M \& Hazel, J 1979. Who's Who in Classical Mythology. Kent: Weidenfeld \& Nicholson.

Hutton, R F 1991. The Pagan Religions of the Ancient British Isles. London: BCA.

Jones, P V 1988. Homer's Odyssey: A Companion to the translation of Richard Lattimore. Bristol: Bristol Classical Press.

Lambert, M 1998. Magic and Religion: Two Sides of the Same Coin? Scholia N S 7: 136-142.

Liddell, H G \& Scott, R 1876. A Lexicon Abridged from Liddell and Scott's GreekEnglish Lexicon ( $17^{\text {th }}$ ed.) Oxford: Clarendon.

Mazur, Z 2003. Unio Magica: On the Magical Origins of Plotinus' Mysticism. Dionysius 21:23-52.

Otis, B 1966. Ovid as an Epic Poet. Cambridge: Cambridge University Press.

Page, D 1973. Folktales in Homer's Odyssey. Cambridge, Massachussets: Harvard University Press.

Seymour, T D 1963. Life in the Homeric Age. New York: Biblo \& Tannen.

Sideman, B B 1970. The World's Best Fairy Tales Vol II. London: The Reader's Digest Association Ltd.

Stanford, W B (ed.) 1967. The Odyssey of Homer Vol I (2nd edition, with alterations and additions). New York: St. Martin's Press.

Weber, C 1999. Dido and Circe Dorees: Two Golden Women in Aeneid 1: 698 and 7: 190. CJ 94(4):317-327.

Whitman, C H 1958. Homer and the Heroic Tradition. Cambridge, Massachussets: Harvard University Press. 